\title{
THE EXPERIENCE OF ORGANIZING A PROBLEM SOLVING LECTURE IN THE MIDDLE OF THE TWENTIETH CENTURY
}

\author{
L. O. Holubnycha \\ Yaroslav Mudryi National Law University \\ 77 Pushkinska Street, Kharkiv, Ukraine, 61024 \\ golubnichaya11@gmail.com, http://orcid.org/0000-0002-8252-9893 \\ O. Yu. Moshynska \\ Yaroslav Mudryi National Law University \\ 77 Pushkinska Street, Kharkiv, Ukraine, 61024 \\ moshaelena1@ukr.net,http://orcid.org/0000-0001-6652-8674
}

\begin{abstract}
The manuscript deals with organizing a problem solving lecture. It describes the experience of higher schools lecturers of the Eastern Ukrainian region in the middle of the twentieth century (the 50-60s). The research is significant because Ukraine seeks to raise the level of higher education and academic staff of the Universities is looking for appropriate forms and methods teaching in order to increase the efficiency of the organization of the student learning process. As leading teachers of the previous period have positive experience of organizing a problem solving lecture it may be useful to study it. The purpose of the article is generalizing features of the problem solving lectures on the basis of the analysis of positive experience of organizing them in higher schools of the Eastern Ukrainian region in the middle of the twentieth century (the 50-60s). The used research methods were general theoretical ones, namely analysis and synthesis of scientific sources under investigation as well as the historical retrospective method applied in historical investigation. The results revealed that lectures, which took more than $50 \%$ of time, played one of the most important roles in the organization of the educational process of Universities. Problem solving lectures were a priority for leading lecturers as they had a number of advantages. They are the following: 1) the problem solving lectures were the most economical way of learning; 2 ) they demonstrated to be efficient as for perception of educational material by students; 3 ) such lectures could be supposed as one of the most efficient ways of forming worldviews and principles; 4) they were a tool of intensification of students' cognitive activity; 5) such lectures motivated students to active listening and participating in the lecture organization; 6) they were realized more accurately, remembered better and gave food for individual further thought. The prospects for further research may become practical, laboratory, seminar and other types of classes based on problem solving method, which were widely used together with the lectures during the studied period.
\end{abstract}

Keywords: problem solving method, lecture, higher school, student, middle of the twentieth century, Eastern Ukrainian region.

\section{Л. О. Голубнича}

Національний юридичний університет імені Ярослава Мудрого

Вулиця Пушкінська 77, Харків, Україна, 61024

\section{О. Ю. Мошинська}

Національний юридичний університет імені Ярослава Мудрого

Вулиця Пушкінська 77, Харків, Україна, 61024

\section{ДОСВІД ОРГАНІЗАЦІЇ ПРОБЛЕМНОЇ ЛЕКЦІЇ В СЕРЕДИНІ ХХ СТОЛІТТЯ}

У статті досліджено проблемний метод організації лекцій. Описано досвід викладачів закладів вищої освіти Східноукраїнського регіону в середині XX століття (50-60-ті роки). Дослідження $\epsilon$ актуальним, адже Україна прагне підвищити рівень вищої освіти, а викладачі вищої школи шукають відповідні форми та методи викладання з метою підвищення ефективності організації навчального процесу студентів. Оскільки провідні викладачі попереднього періоду мають позитивний досвід організації лекції проблемного характеру, може бути корисним вивчення цього досвіду. Метою статті $€$ узагальнення особливостей лекцій проблемного характеру на основі аналізу позитивного досвіду 
2020 Випуск/ Issue 47

їх організації у вищих школах Східноукраїнського регіону в середині XX століття (50-60-ті роки). Використані методи дослідження були загальнотеоретичними, а саме аналіз та синтез досліджуваних наукових джерел, а також було використано історично- ретроспективний підхід, що застосовується до історичних досліджень. Результати наукової розвідки показали, що лекції, які займали понад 50\% часу, відігравали одну з найважливіших ролей в організації навчального процесу вищої школи. Лекції проблемного характеру були пріоритетними для провідних викладачів, оскільки вони мали ряд переваг, а саме: 1) проблемні лекції були найбільш економічним способом навчання; 2) вони продемонстрували свою ефективність щодо сприйняття студентами навчального матеріалу; 3) такі лекції можна вважати одним із найефективніших способів формування світогляду та принципів; 4) вони були інструментом активізації пізнавальної діяльності студентів; 5) такі лекції спонукали студентів до активного слухання та участі в організації лекції; 6) студенти точніше розуміли навчальний матеріал та краще запам'ятовували його, що давало їм їжу для подальшої самостійної пізнавальної діяльності. Перспективами подальших досліджень можуть стати практичні, лабораторні, семінарські та інші види занять, організовані із застосуванням проблемного методу, адже вони широко використовувались разом з лекціями протягом досліджуваного періоду.

Ключові слова: проблемний метод навчання, лекція, вища школа, студент, середина XX століття, Східноукраїнський регіон.

\section{Л. А. Голубничая}

Национальный юридический університет имени Ярослава Мудрого

Улица Пушкинская 77, Харьков, Украина, 61024

\section{Е. Ю. Мошинская}

Национальный юридический університет имени Ярослава Мудрого

Улица Пушкинская 77, Харьков, Украина, 61024

\section{ОПЫТ ОРГАНИЗАЦИИ ПРОБЛЕМНОЙ ЛЕКЦИИ В СЕРЕДИНЕ ХХ СТОЛЕТИЯ}

В статье исследован проблемный метод организации лекций. Описан опыт преподавателей высших учебных заведений Восточноукраинского региона в середине XX века (50-60-е годы). Исследование является актуальным, поскольку Украина стремится повысить уровень высшего образования, а преподаватели высшей школы ищут соответствующие формы и методы преподавания с целью повышения эффективности организации учебного процесса студентов. Так как ведущие преподаватели предыдущего периода имели положительный опыт организации лекции проблемного характера, может быть полезным изучение этого опыта. Целью статьи является обобщение особенностей лекций проблемного характера на основе анализа положительного опыта их организации в высших школах Восточноукраинского региона в середине XX века (50-60-е годы). Использованные методы исследования были общетеоретическими, а именно анализ и синтез исследуемых научных источников, а также был использован историко-ретроспективный подход, применяемый к историческим исследованиям. Результаты научного исследования показали, что лекции, которые занимали более $50 \%$ времени, играли одну из важнейших ролей в организации учебного процесса высшей школы. Лекции проблемного характера были приоритетными для ведущих преподавателей, поскольку они имели ряд преимуществ, а именно: 1) проблемные лекции были наиболее экономичным способом обучения; 2) они продемонстрировали свою эффективность по восприятию студентами учебного материала; 3) такие лекции можно считать одним из самых эффективных способов формирования мировоззрения и принципов; 4) они были инструментом активизации познавательной деятельности студентов; 5) такие лекции побуждали студентов к активному слушанию и участия в организации лекции 6) студенты точнее воспринимали учебный материал и лучше запоминали его, что давало им пищу для дальнейшей самостоятельной познавательной деятельности. Перспективами дальнейших исследований могут стать практические, лабораторные, семинарские и другие виды занятий, организованые с применением проблемного метода, ведь они широко использовались вместе с лекциями в течение исследуемого периода.

Ключевые слова: проблемный метод обучения, лекция, высшая школа, студент, середина XX века, Восточноукраинский регион.

Introduction. With a huge scientific potential, Ukraine seeks to develop domestic science, a necessary prerequisite for which is, on the one hand, raising the level of higher education, and on the other hand, understanding the lessons of history to avoid mistakes and transfer valuable experience to the present. Thus, the 50-60s of the last century are characterized by the completion of the stage of the higher education classical Soviet system development. Didactic ideas of the second half of the twentieth century were reflected in the practice of universities of Ukraine in the period under study. In particular, the leading teachers of the second half of the last century paid considerable attention to the search for forms and methods of the tertiary level teaching that would help increase the 
efficiency of the organization of the student learning process. Among the forms and methods that have proven themselves on the positive side there are problem solving lectures. So it is significant to study the experience of organizing them.

Analysis of recent research and publications shows that the experience of organizing educational and cognitive activities of the tertiary level, as well as its forms and methods, such as lectures were the subject of research by a large number of domestic scientists. Thus, back in the $60 \mathrm{~s}$ and 70s the issue of the lecture organization and its effectiveness was studied by A. Kireiev [4], V. Viktorov \& I. Kapelyushny [3], N. Polovnikova [16], I. Reinhard [17], and others. I. Kobylyatsky [5], E. Myshyna [9] and others taught their own positive experience as for the lecture organization on the pages of the pedagogical periodicals. O. Cherednyk [19], L. Holubnycha [20], M. Oksa [13], O. Orlova [14; 15] and others considered the historical aspect of this issue. Teaching through problem solving method was discovered by A. Furman [18], L. Mahan [22], V. Maheshwari [23], M. Makhmutov [8], V. Manko [6], A. Matyushkin [7], V. Okon [12], V. Ruggiero [24] and others.

However, the coverage of the experience of organizing a problem solving lecture in the Eastern region of Ukraine in the middle of the twentieth century (the 50-60s), when the classical system of Soviet higher school was completed, has not been sufficiently reflected in the researches on pedagogical history.

Objective. The purpose of the manuscript is to generalize features of the problem solving lectures on the basis of the analysis of positive experience of organizing them in higher schools of the East Ukrainian region in the middle of the twentieth century (the 50-60s).

Methods. As our research is not experimental but theoretical we have used appropriate general theoretical research methods such as analysis and synthesis of scientific sources under investigation as well as the historical retrospective method. All the mentioned allowed us to discover, analyse and generalize the necessary information on the issue.

Results. The analysis of sources [21]: didactic - protocols of meetings of the Academic Council of T.G. Shevchenko Voroshilovgrad Pedagogical Institute, the Council of Horlivka State Pedagogical Institute of Foreign Languages, the Council of Slaviansk State Pedagogical Institute; textbooks and narrative - researches suggests that the practice of higher schools in the Eastern region of Ukraine reflects the following didactic ideas of the middle (the 50-60s) of the twentieth century (active creation and application of new pedagogical technol- ogies together with problem solving teaching, development of effective didactic concepts, creative preparation of materials to optimize the learning process, introduction of technical teaching aids, many new educational programs, etc.). In particular, the leading teachers of this period paid considerable attention to the search for forms and methods that would help increase the efficiency of the organization of the student learning process.

In the course of scientific investigation it was established that at the period under study in higher schools of the East Ukrainian region there were such forms of classes' organization as lectures, practical, seminars, consultations, laboratory workshops, as well as various teaching methods (algorithmic, search, problem, research etc.). Problem solving method of teaching was given priority by leading lecturers.

The analysis of curricula of teachers of the tertiary level of the mentioned region and period by scientists of the studied period and region shows that an important role in the organization of the educational process was played by lectures, which took more than $50 \%$ of time. This was explained by the fact that this form of education had the following advantages: 1) the most economical way of learning; 2) effective in the degree of assimilation of educational material by students; 3 ) one of the most effective means of forming worldviews and beliefs; 4) a means of direct personal influence of the lecturer on a large audience at the same time. Considering problem solving lectures, according to the teachers, who organized them [5; 9], they had not only the listed benefits but also intensified students' cognitive activity, motivated them to active listening and participating in the lecture organization, were realized more accurately, remembered better and gave food for individual further thought.

Speaking about additional specifics of such lectures, modern Kharkiv researcher of the organization of educational and cognitive activities of students in higher pedagogical educational institutions of Ukraine in the second half of XX century 0 . Cherednyk determined the leading place of the lecture in the educational process of the studied period by the fact that: firstly, the course of lectures on the discipline conveyed its main content; secondly, it was the lectures that regulated not only the content, but also the ideological-theoretical and professional orientation of the whole educational process; thirdly, the direction, content and effectiveness of other forms of educational process depended on lectures [19]. Nowadays as we can see there were certain influence of the time on the lecture and problem solving as well. 
Thus, studying any problem in historical perspective, to be able to evaluate facts properly it is natural and important to reveal specific features of the period under research. In our case it is the influence of governmental policy on the organization of the educational process in higher school in general, including in the Eastern region of Ukraine. Consequently, the mentioned concerned problem solving lectures.

So, on March 16-17, 1950, the resolution of the third plenum of the Scientific and Methodological Council at the Ministry of Higher Education of the USSR "On Improving the Quality of Lectures in Higher Educational Institutions" was adopted. According to this document, the lecture was to present the basic concepts of the studied discipline, to outline ways to further its deeper study; to cover the basic principles, the main issues of the course scientifically and logically, without overloading it with unnecessary details; to be based on the principle of Bolshevik party teaching and to introduce students to a specific branch of science, to reveal the Marxist-Leninist methodology of the subject and to serve as a school of thinking, to acquaint with the main directions of science development and solving the main scientific issues of that time [11, p. 90].

Analysis of didactic sources (protocols of meetings of the Council of the Slaviansk State Pedagogical Institute), documentary (act) and narrative (scientific) on the organization of the educational process in higher school in the Eastern region shows that, following the given resolution, a lecture (as well as problem solving one) as the main form of study in the mentioned period had a number characteristic features, in particular: 1) holistically and logically covered the main provisions of the discipline; 2) armed students with the methodology of studying a particular science; 3 ) better and more fully than other forms of education, compensated for the obsolescence or absence of modern textbooks and manuals; 4) promptly acquainted students with the latest data of science; 5) organically combined learning and education; 6) aimed students at independent work and determined its main directions.

At the same time, the studied source base allows us to state that the problem solving lecture had some shortcomings, in particular the lecture: 1) could not generally deviate from the main works, textbooks, axioms and truths; 2) provided not very big feedback from the lecturer to students; 3 ) had the weaker impact on a particular student, the more listeners there were in the lecture hall. Among other shortcomings of the lectures of that time is the politicization of lecture materials.
Analysis of pedagogical periodicals of the studied period, where the leading teachers shared their positive experience of organizing lectures, allows us to assert that educational lectures of that time were divided into three types: review, subject and problem solving. The review lecture was aimed at restoring previous knowledge or getting acquainted with any unexplored or unfamiliar material for the development of holistic knowledge. The subject lecture was a regular part of the lecture course, although it could well contain elements of both review and problem solving. Problem solving lecture presented the material as a problem, a palette of different views on a particular issue. The method of problem-based presentation of knowledge had a direct relation to the problem solving lecture in a higher educational institution by the nature of the interconnected activity of the teacher and students. Taking into account the peculiarities of problem thinking and intensification of students'cognitive activity with the help of heuristic methods provided a problem-based approach to the presentation of lecture material.

In the context of the mentioned the positive example of creating problem solving situations can be found at O.M. Gorky Kharkiv State University [3]. So, in lectures on mathematics, Professor D. Hordevskyi used elements of a short dialogue with the audience to enhance the cognitive activity of students. During the lecture, the teacher posed several problems and solved them together with the students. He also gave students possibility to formulate certain definitions and conclusions, required independent action. No more than 1012 mini-problems were created during each the lecture, which were solved by students. It took 1-2 minutes to solve every one, and in general - up to 20 minutes of active, creative activity of students. After that, the information provided by the teacher was perceived as essential [3, p. 122].

Nevertheless, despite the use of methods of intensification students' cognitive activity, one of the difficulties of that time was the low success of first- and second-year students, as evidenced by the analysis of didactic sources (protocols of council meetings) and documentary (directives, orders of higher education institutions of the Eastern region). Specific measures, such as simplifying lectures (practically they approached to school level), introducing compulsory counseling, introducing test-taking on specific topics, etc., did not improve the situation. This gave all grounds to the state leadership on the part of higher education to believe that "a way out of this situation could be sought only by optimizing the educational process". It was 
indicated in the collection of basic regulations, orders and instructions on higher education [2, p. 136].

Fortunately in the early 60 's of the twentieth century the role of the lecturer changed radically because of the party's 1960 guideline. According to it, "one of the most important issues in the restructuring of higher education, on which the organization of the educational process depends, is the creative development and implementation of new curricula, which determine the strengthening of theoretical training and close combination of production and social work" [1, p. 72]. Thus, from the beginning of the 1959/60 academic year, all higher educational institutions of Ukraine began to work according to new curricula, where the number of hours for independent work of students was increased [1, p. 6]. As a result, the main task of a lecturer was no longer to transfer information from the course being read, but to create problems and situations that would arouse students' interest in the presented material, which became an incentive for further self-study. Thus, in the process of teaching and learning there was a tendency to change the methodology of the lecture in direction of problem solving method.

According to the analysis of the experience of higher education in the Eastern region of Ukraine $[3 ; 9 ; 13 ; 15]$ teachers of higher education institutions of the studied period chose a problem solving structure of the lecture because it objectively provided for the cognitive activity and mental independence of students. An experience of A. Petrov, who was a lecturer of O.M. Gorky Kharkiv State University and used problem solving method of organizing the lecture, can be an example of this [14]. Thus, in advance his students got acquainted with the lecture plan, which was composed of a series of problems or cases. At the request of students, they chose individual issues and worked on them (selected literature themselves, solved the problem or the case and independently prepared reports for 9-10 minutes, in which they stated their solution of the problem). A. Petrov consulted the students, who were preparing for the speech, helped them with advice. The lecture was started by the teacher himself. He gradually brought the listeners to the questions prepared by the students. After that there was a joint discussion of the reports, the teacher led the students to the conclusion, which they were making independently [14].

The organization of the lecture according to the above method supported the creative search, developed the independence of thinking, skills of analysis and synthesis of factual material that was already available, helped to establish cause-and- effect relationships, select the necessary information. In addition, students under the guidance of a teacher gained experience of working with scientific literature, developed skills of generalization of scientific data.

In the course of research it was found that the lecture of the 60's of the previous century was characterized by the use ofvarious ways oftheproblem solving method that intensified the independent cognitive activity of students, stimulated them to be educationally active at the lecture. Another example may be an experience of a lecturer at the Faculty of Chemistry of O.M. Gorky Kharkiv State University I. Ostapenko, who during a lecture on chemistry gave a definition of hydrolysis and considered the main issues of its reaction. After that, the teacher stated problems and helped to solve it through asking about different chemical elements. For instance, "Is it possible or not (and why?) to record the reaction of hydrolysis of sodium chloride?" If students listened carefully and thoughtfully they understood and could solve the stated problem answering correctly. This questions attracted the attention of the audience, activated the thinking of students, taught them to critically evaluate, analyze independently, compare facts, draw logical conclusions [9].

As another effective way of a problem solving method that intensified students' educational and cognitive activities, which has been revealed in the practice of higher education in the Eastern region of the period under study, may be considered techniques when some part of the material was presented of in the form of questions and answers, evidence and solutions to cognitive problems. The ways of scientific and logical thinking were demonstrated to students. This approach allowed to get the feedback, as well as to focus on key issues of the topic. Analyzing difficult situations with students, the lecturer gradually brought them to the topic of the lecture and formulated a problem that needed to be solved. The creation of a cognitive situation at the beginning of the lecture aroused interest in the material studied, intensified the educational and cognitive activities of students, contributed to the formation of mental independence of the individual [10].

The study of the experience of higher educational institutions of the Eastern Ukraine in the period under study shows that lecturers did not limit themselves to the use of traditional forms and methods within reproductive education, but tried to organize student education so that it promoted the development of perfect skills to learn the reality, to acquire knowledge, as well as for to use them creatively in future professional activities.

Discussion and conclusions. Thus, the conducted research and the review of sources on 
the experience of organizing a problem solving lecture in the Eastern Ukraine in the middle of the twentieth century (the 50-60s) allows us to conclude that lectures played a very important role in the organization of the educational process of higher school as they took more than $50 \%$ of time. Problem solving method of giving a lecture was a priority for leading lecturers. There were more benefits of such lecturers than of ordinary ones and they can be seen as follows: 1) the problem solving lectures were the most economical way of learning; 2) they demonstrated to be efficient as for perception of educational material by students; 3 ) such lectures could be supposed as one of the most efficient ways of forming worldviews and principles; 4) they were a tool of intensification of students' cognitive activity; 5) such lectures motivated students to active listening and participating in the lecture organization; 6) they were realized more accurately, remembered better and gave food for individual further thought.

However, in the Soviet higher school the organization of the educational process was clearly regulated by documents of the Ministry of Higher Education of the USSR, so differences between lectures, which at that time were almost unique source of knowledge, consisted only in the level of mastery of the lecturers' pedagogical skills.

As practical, laboratory, seminar and other types of classes were widely used together with the lectures based on problem solving method, we consider them to be prospects for further research.

\section{СПИСОК ВИКОРИСТАНИХ ДЖЕРЕЛ ТА ЛІТЕРАТУРИ:}

1. Вища освіта на новому етапі : з досвіду перебудови вищої школи на Україні. Київ : Держ. вид-во л-ри УРСР, 1961. 239 c.

2. Высшая школа : сборник основних постановлений, приказов и инструкций : в 2 ч. Ч. 1. Москва : Высш. шк., 1978. 399 с.

3. 3 досвіду роботи педагогічних вузів Української РСР [упоряд. В. О. Вікторов, І. В. Капелюшний]. Київ : Рад. шк., 1964. 148 с.

4. Киреев А. Ф. Лекция в высшей школе. Москва, 1961. 78 с.

5. Кобыляцкий И. И. Учебный процесс в высшей школе. Советская педагогика, 1970. № 8. С. 92-102.

6. Манько В. А. Проблемне навчання як актуальна науково-педагогічна проблема. Засоби навчальної та науково-дослідної роботи. Харків, 2006. Вип. 25. С. 102-106.

7. Матюшкин А. М. Проблемные ситуации в мышлении и обучении. Москва : Педагогика, 1972.208 с.

8. Махмутов М.И. Организация проблемного обучения в школе. Книга для учителей. Москва: Просвещение, 1977. $240 \mathrm{c}$.

9. Мишина Е. Ф. Новое в методике изучения химии. Вестник высшей школы, 1965. № 7. С. 42-44.

10. Наумець О. Ідеал вчителя в історії педагогіки. Наукові записки, 2002. Вип 41. С. 112-116.

11. О повышении качества лекций в высших учебных заведениях : из постановления пленума научнометодического совета при Министерстве высшего образования СССР 16-17 марта 1950 г. Высшая школа : сб. основ. постановлений, приказов, инструкций. Москва, 1965. С. 89-91.

12. Оконь В. Основы проблемного обучения. Пер. с польск. Москва : Просвещение, 1968. 208 с.

13. Окса М. М. Вивчення дисциплін загально-педагогічної підготовки вчителя у педагогічних вузах України (1917-1991 рр.). Київ : Міжнар. фін. агенція, 1997. 315 с.

14. Орлова О. О. Напрями розвитку розумової самостійності в сучасних умовах. Сучасна освіта в умовах реформування : проблеми, теорія, практика : наук.-практ конф., 22 листоп. 2011 р. Харків, 2011. С. 79-80.

15. Орлова О. О. Роль викладача у формуванні розумової самостійності студентів (друга половина XX ст.) Освіта і доля нації : ХІІ міжнар. наук.-практ. конф., 20-21 трав. 2011 р. Харків, 2011. С. 72-80.

16. Половникова Н. А. Воспитание познавательной состоятельности. Казань: Татар. книж. изд., 196868 с.

17. Рейнгард И. А. Формы и методы преподавания в высшей школе. Днепропетровск : Днепр, 1973.76 с.

18. Фурман А. В. Проблемні ситуації в навчанні : кн. для вчителя. - Київ : Рад. Школа, 1991. 191 с.

19. Чередник О. В. Організація навчально-пізнавальної діяльності студентів у вищих педагогічних навчальних закладах України (друга половина XX століття) : автореф. дис на здобуття наук. ступеня канд. пед. наук : спец. 13.00.01 «Загальна педагогіка та історія педагогіки». Харків, 2012.20 с.

20. Holubnycha, L. O. (2016). Experience of Intensification of Students' Cognitive Activity in the USSR (Postwar Period the Middle of the 20-th Century). International Letters of Social and Humanistic Sciences, 73, 1 - 6.

21. Holubnycha, L., Kostikova, I., Maslova, N., Tanko, A., \& Sikora, V. (2019). Modern Types of Historiographic Sources in Pedagogy. Revista Romaneasca pentru Educatie Multidimensionala, 11 (2), 326 - 340. Retrieved from: http:// dx.doi.org/10.18662/rrem/133

22. Mahan, L. A. (1967). What is the solving problem method of teaching. Retrieved from: https://onlinelibrary. wiley.com/doi/abs/10.1002/sce.3730510405

23. Maheshwari, V. K. (2017) The Problem Solving Method in Education Retrieved from: http://www.vkmaheshwari. com/WP/?p=2375

24. Ruggiero, V. R. (1998). Beyond Feelings. A Guide to Critical Thinking. Mayfield Publ. Co. 96 p. 


\section{REFERENCES:}

1. Vyshcha osvita na novomu etapi : $\mathrm{z}$ dosvidu perebudovy vyshchoyi shkoly na Ukrayini. (1961). [Higher education at a new stage: from the experience of restructuring higher education in Ukraine]. Kyiv : Derzh. vyd-vo l-ry URSR. (in Ukrainian).

2. Vysshaya shkola : sbornik osnovnikh postanovleniy, prikazov i instruktsiy : v 2 ch. CH. 1. (1978). [Higher school: a collection of basic decrees, orders and instructions]. Moskva : Vyssh. shk. (in Russian).

3. Viktorov, V. O., Kapelyushnyy, I. V. (1964). Z dosvidu roboty pedahohichnykh vuziv Ukrayins'koyi RSR. [From the experience of pedagogical universities of the Ukrainian SSR]. Kyyiv : Rad. shk. (in Ukrainian).

4. Kireyev, A. F. (1961). Lektsiya v vysshey shkole. [Lecture in higher school]. Moskva. (in Russian).

5. Kobylyatskiy, I. I. (1970). Uchebnyy protsess v vysshey shkole. [The educational process in higher education]. Sovetskaya pedagogika. 8. pp. 92-102. (in Russian).

6. Man'ko, V. A. (2006). Problemne navchannya yak aktual'na naukovo-pedahohichna problema. [Problem-based learning as an actual scientific and pedagogical problem]. Zasoby navchal'noyi ta naukovo-doslidnoyi roboty. Kharkiv. 25. pp. 102-106. (in Ukrainian).

7. Matyushkin, A. M. (1972). Problemnyye situatsii v myshlenii i obuchenii. [Problem based situations in thinking and learning]. Moskva : Pedagogika. (in Russian).

8. Makhmutov, M. I. (1977). Organizatsiya problemnogo obucheniya v shkole. Kniga dlya uchiteley. [Organization of problem solving learning at school. A book for teachers]. Moskva : Prosveshcheniye. (in Russian).

9. Mishina, Ye. F. (1965). Novoye v metodike izucheniya khimii. [New in the method of studying chemistry]. Vestnik vysshey shkoly. 7. pp. 42-44. (in Russian).

10. Naumets,' O. (2002). Ideal vchytelya v istoriyi pedahohiky. [The ideal teacher in the history of pedagogy]. Naukovi zapysky. 41. pp. 112-116. (in Ukrainian).

11. O povyshenii kachestva lektsiy $\mathrm{v}$ vysshikh uchebnykh zavedeniyakh : iz postanovleniya plenuma nauchnometodicheskogo soveta pri Ministerstve vysshego obrazovaniya SSSR 16-17 marta 1950 g. (1965). [On improving the quality of lectures in higher educational institutions: from the decree of the plenum of the scientific and methodological council at the Ministry of Higher Education of the USSR March 16-17, 1950]. Vysshaya shkola : sb. osnov. postanovleniy, prikazov, instruktsiy. Moskva. pp. 89-91. (in Russian).

12. Okon', V. (1968). Osnovy problemnogo obucheniya. [Fundamentals of problem solving learning]. Moskva : Prosveshcheniye. (in Russian).

13. Oksa, M. M. (1997). Vyvchennya dystsyplin zahal'no-pedahohichnoyi pidhotovky vchytelya u pedahohichnykh vuzakh Ukrayiny (1917-1991 rr.). [Study of disciplines of general pedagogical training of teachers in pedagogical universities of Ukraine (1917-1991)]. Kyyiv : Mizhnar. fin. ahentsiya. (in Ukrainian).

14. Orlova, O. O. (2011). Napryamy rozvytku rozumovoyi samostiynosti v suchasnykh umovakh. [Directions of development of mental independence in modern conditions]. Suchasna osvita $v$ umovakh reformuvannya : problemy, teoriya, praktyka. Kharkiv, pp. 79-80. (in Ukrainian).

15. Orlova, O. O. (2011). Rol' vykladacha u formuvanni rozumovoyi samostiynosti studentiv (druha polovyna XX st.). [The role of the teacher in the development of mental independence of students (second half of the twentieth century.)]. Osvita i dolya natsiyi. Kharkiv, pp. 72-80. (in Ukrainian).

16. Polovnikova, N. A. (1968). Vospitaniye poznavatel'noy sostoyatel'nosti. [Education of cognitive competence.]. Kazan' : Tatar. knizh. izd. (in Russian).

17. Reyngard, I. A. (1973). Formy i metody prepodavaniya v vysshey shkole. [Forms and methods of teaching in higher education] Dnepropetrovsk : Dnepr. (in Russian).

18. Furman, A. V. (1991). Problemni sytuatsiyi v navchanni : kn. dlya vchytelya. [Problem based situations in education : book for the teacher]. Kyiv : Rad. Shkola. (in Ukrainian).

19. Cherednyk, O. V. (2012). Orhanizatsiya navchal'no-piznaval'noyi diyal'nosti studentiv u vyshchykh pedahohichnykh navchal'nykh zakladakh Ukrayiny (druha polovyna XX stolittya). [Organization of educational and cognitive activity of students in higher pedagogical educational institutions of Ukraine (second half of XX century)]. (Abstract of candidate's thesis). Kharkiv, Ukraine. (in Ukrainian).

20. Holubnycha, L. O. (2016). Experience of Intensification of Students' Cognitive Activity in the USSR (Postwar Period the Middle of the 20-th Century). International Letters of Social and Humanistic Sciences. 73. pp. 1 - 6.

21. Holubnycha, L., Kostikova, I., Maslova, N., Tanko, A., \& Sikora, V. (2019). Modern Types of Historiographic Sources in Pedagogy. Revista Romaneasca pentru Educatie Multidimensionala. 11 (2). pp. 326 - 340. Retrieved from: http://dx.doi.org/10.18662/rrem/133

22. Mahan, L. A. (1967). What is the solving problem method of teaching. Retrieved from: https://onlinelibrary. wiley.com/doi/abs/10.1002/sce.3730510405

23. Maheshwari, V. K. (2017) The Problem Solving Method in Education Retrieved from: http://www.vkmaheshwari. com/WP/?p=2375

24. Ruggiero, V. R. (1998). Beyond Feelings. A Guide to Critical Thinking. Mayfield Publ. Co. 